\title{
PENGARUH BUDAYA KERJA DAN DISIPLIN KERJA TERHADAP KINERJA APARATUR SIPIL NEGARA PADA BIRO ADMINISTRASI RUMAH TANGGA PIMPINAN SEKRETARIAT DAERAH PROVINSI BANTEN
}

\author{
Ferlita Widyawati ${ }^{1}$, Edi Mulyadi ${ }^{1}$, Anen Tumanggung ${ }^{1}$ \\ ${ }^{1}$ Program Pascasarjana UNIS Tangerang \\ Email: ferlitawidyawati@gmail.com
}

\begin{abstract}
Abstrak
Penelitian ini bertujuan untuk menganalisis pengaruh Budaya Kerja dan Disiplin Kerja terhadap Kinerja Aparatur Sipil Negara di Biro Administrasi Rumah Tangga Pimpinan Sekretariat Daerah Provinsi Banten. Metode pendekatan penelitian yang digunakan dalam penelitian ini yaitu metode korelasi untuk melihat seberapa besar pengaruh variabel bebas dan variabel terikat. Populasi penelitian ini adalah seluruh pegawai di Biro Administrasi Rumah Tangga Pimpinan Sekretariat Daerah Provinsi Banten sebanyak 58 orang. Penentuan sampel dengan menggunakan total teknik sampling, sehingga jumlah sampel dalam penelitian ini sebanyak 58 orang. Setiap responden diberikan sebanyak 39 pertanyaan dengan menggunakan angket skala likert. Data di analisis dengan menggunakan analisis jalur (Path Analysisi). Teknik pengumpulan data yang digunakan adalah studi pustaka, observasi dan angket. Pengolahan data dibantu dengan program SPSS for Windows versi 17. Dari hasil pengolahan data diketahui bahwa budaya kerja berpengaruh positif dan signifikan terhadap kinerja aparatur sipil negara dimana pengaruh langsung dari budaya kerja terhadap terhadap kinerja aparatur sipil negara adalah $22,4 \%$ sedangkan pengaruh tidak langsungnya adalah 25,8 \% dengan besarnya pengaruh total adalah 48,2 \% . Ditemukan pula bahwa disiplin kerja berpengaruh positif dan signifikan terhadap kinerja aparatur sipil negara dimana pengaruh langsung dari budaya kerja terhadap terhadap kinerja aparatur sipil negara adalah 3,3\% sedangkan pengaruh tidak langsungnya adalah $25,8 \%$ dengan besarnya pengaruh total adalah $29,1 \%$. Budaya kerja dan disiplin kerja secara bersama-sama berpengaruh positif dan signifikan terhadap kinerja aparatur sipil negara dimana pengaruh langsung dari budaya kerja terhadap terhadap kinerja aparatur sipil negara adalah 48,2 $\%$ sedangkan pengaruh tidak langsungnya adalah $29,1 \%$ dengan besarnya pengaruh total adalah 77,3 \%. Hasil penelitian menunjukkan bahwa ada pengaruh positif dan signifikan dari Budaya Kerja dan Disiplin Kerja baik secara parsial maupun simultan terhadap Kinerja Aparatur Sipil Negara.
\end{abstract}

Kata Kunci: Budaya Kerja, Disiplin Kerja dan Kinerja

\section{A. Pendahuluan}

Suatu organisasi atau perusahaan jika ingin maju atau berkembang maka dituntut untuk memiliki pegawai yang berkualitas. Pegawai yang berkualitas adalah pegawai yang kinerjanya dapat memenuhi target atau sasaran yang ditetapkan oleh suatu organisasi atau perusahaan. Untuk memperoleh pegawai yang memiliki kinerja baik maka diperlukan penerapan kinerja.

Ukuran kinerja dapat dilihat dari sisi jumlah dan mutu tertentu sesuai dengan standar yang telah ditetapkan oleh organisasi atau perusahaan bentuknya dapat bersifat tangible (dapat ditetapkan alat ukurnya atau standarnya) atau intangible (tak dapat ditetapkan alat ukurnya atau standarnya), tergantung pada bentuk dan proses pelaksanaan pekerjaan itu. Kinerja yang dihasilkan oleh pegawai dalam suatu organisasi ditentukan oleh beberapa faktor dan kondisi yang baik itu yang berasal dari dalam diri pegawai ataupun yang berasal dari luar individu pegawai.

Kinerja sebagai tingkat keberhasilan di dalam melaksanakan tugas serta kemampuan untuk mencapai tujuan yang telah ditetapkan. Kinerja dikatakan baik dan sukses jika tujuan yang diinginkan dapat dicapai dengan baik. Efesiensi dan efektifitas merupakan dua aspek penting dalam menilai suatu kinerja. Efesiensi adalah perbandingan antara hasil yang dicapai dengan usaha yang dikeluarkan, sedangkan efektifitas adalah perbandingan antara hasil yang dicapai dengan hasil yang diharapkan.

Kinerja Aparatur Sipil Negara merupakan salah satu unsur utama dalam menunjang pencapaian tujuan organisasi pada Biro Administrasi Rumah Tangga Pimpinan Sekretariat Daerah Provinsi Banten. Kinerja Aparatur Sipil Negara yang merupakan subsistem dari sistem yang terdapat pada Biro Administrasi Rumah Tangga Pimpinan Sekretariat Daerah Provinsi Banten akan 
dipengaruhi oleh beberapa faktor, baik yang bersifat intenal maupun eksternal. Kinerja Aparatur Sipil Negara yang lemah akan menghambat kinerja pada Biro Administrasi Rumah Tangga Pimpinan Sekretariat Daerah Provinsi Banten secara keseluruhan.

Realita yang terjadi pada Biro Administrasi Rumah Tangga Pimpinan Sekretariat Daerah Provinsi Banten, berkaitan dengan kinerja Aparatur Sipil Negara cukup mendapat perhatian yang serius dari berbagai pihak, terutama dari unsur pimpinan. Sebab pimpinan merupakan salah satu elemen yang sentral dalam menentukan kebijakan serta roda birokrasi pada organisasi. Lemahnya kinerja Aparatur Sipil Negara pada Biro Administrasi Rumah Tangga Pimpinan Sekretariat Daerah Provinsi Banten dapat terlihat dari berbagai fenomena yang muncul selama ini, diantaranya adalah keteladanan pemimpin untuk memberi contoh kepada bawahannya masih rendah, kurangnya pemberian penghargaan dan hukuman terhadap penegakan kinerja pegawai, kesadaran pegawai untuk meningkatkan disiplin kerja masih kurang, konsistensi kebijakan disiplin yang diterapkan terhadap pegawai masih kurang, komunikasi yang efektif dan efisien belum terbina dengan baik, serta budaya kerja yang ada masih rendah.

Kemampuan pegawai tercermin dari kinerja, kinerja yang baik adalah kinerja yang optimal. Kinerja pegawai tersebut merupakan salah satu modal bagi pemerintah untuk mencapai tujuannya. Sehingga kinerja pegawai adalah hal yang patut diperhatikan oleh pemimpin.

Berdasarkan hasil pengamatan sementara, Kinerja Aparatur Sipil Negara yang ada pada Biro Administrasi Rumah Tangga Pimpinan Sekretariat Daerah Provinsi Banten masih lemah. Hal ini diduga disebabkan oleh adanya faktor Budaya Kerja dan Disiplin Kerja. Selain itu adanya faktor lain diduga juga dapat mempengaruhi Kinerja Aparatur Sipil Negara yaitu diantaranya pendidikan dan pelatihan, perencanaan sumber daya manusia, lingkungan kerja, komunikasi, kompetensi jabatan, pendidikan formal, budaya organisasi, motivasi, kualitas sumber daya manusia, kompensasi, kepemimpinan, gaya kepemimpinan, koordinasi, dan lain-lain.

Kinerja merupakan hasil kerja yang dapat dicapai oleh seseorang dalam suatu organisasi, sesuai dengan wewenang dan tanggung jawab masing-masing, dalam rangka upaya mencapai tujuan organisasi bersangkutan secara legal, tidak melanggar hukum dan sesuai dengan moral maupun etika. Kata kinerja juga dapat diartikan sebagai kemampuan yang menunjukkan kesungguhan seseorang dalam melaksanakan pekerjaannya. Disamping itu, kinerja juga dapat bermakna sebagai ukuran dari suatu hasil kerja.

Kinerja dapat pula diartikan sebagai perwujudan kerja yang dilakukan oleh pegawai dan biasanya dipakai sebagai dasar penilaian terhadap pegawai atau individu. Kinerja yang baik merupakan suatu langkah untuk menuju tercapainya tujuan individu. Oleh karena itu kinerja merupakan sasaran penentu dalam mencapai tujuan individu. Kinerja merupakan perwujudan kerja yang dilakukan oleh pegawai yang biasanya dipakai sebagai dasar penilaian terhadap pegawai atau organisasi, sehingga perlu diupayakan untuk meningkatkan kinerja.

Pada Sekretariat Daerah Provinsi Banten dipimpin oleh seorang Sekretaris Daerah yang berkedudukan dibawah dan bertanggung jawab kepada Gubernur. Biro Administrasi Rumah Tangga Pimpinan Sekretariat Daerah Provinsi Banten mempunyai tugas pokok membantu Asisten Daerah Administrasi Umum dalam melaksanakan pembinaan, koordinasi, evaluasi, dan perumusan kebijakan di bidang umum, urusan rumah tangga, dan keuangan Sekretariat Daerah.

Kemampuan dan keterampilan mempunyai peran yang erat terhadap kinerja, di samping faktor personaliti yaitu konsep diri dan sikap. Kemampuan dan keterampilan merupakan suatu persyaratan bagi keberhasilan dalam suatu proses perwujudan kinerja. Kemampuan dan keterampilan ini berupa penguasaan konsep, kemampuan teknis, dan hubungan interpersonal. Kemampuan adalah suatu daya untuk melakukan tindakan yang merupakan hasil dari pembawaan atau latihan, karena itu kemampuan menunjukkan bahwa seseorang dapat atau tidak dapat melakukan, suatu aktivitas yang juga merupakan faktor utama yang menentukan kinerja seseorang. Keterampilan dan kemampuan untuk melakukan setiap pekerjaan dilandasi oleh pendidikan dan latihan yang memadai akan membantu tercapainya Komunikasi yang berkualitas. Peningkatan-kualitas yang diharapkan memberikan outcome dalam 
bentuk perubahan: pengetahuan yang dimiliki, sikap, kemampuan dan perilaku individu atau kelompok.

Kinerja Aparatur Sipil Negara dipengaruhi oleh faktor Budaya Kerja. Budaya kerja diartikan sebagai kelompok pikiran dasar atau program mental yang dapat dimanfaatkan untuk meningkatkan efisiensi dan efektivitas kerja serta kerja sama manusia yang dimiliki oleh suatu golongan masyarakat. Budaya kerja dapat dilihat dari aspek sikap terhadap pekerjaan, perilaku ketika bekerja, kenampakan, dan etos kerja.

Berdasarkan hasil observasi pada Biro Administrasi Rumah Tangga Pimpinan Sekretariat Daerah Provinsi Banten, budaya kerja yang ada masih rendah, hal ini dapat terlihat dari adanya pelanggaran-pelanggaran yang dilakukan oleh pegawai seperti adanya pegawai yang datang ke kantor terlambat, kedatangan pegawai pada pagi hari yang seharusnya jam 07.30 mereka banyak yang datang di atas jam 08.00, sehingga dengan keadaan ini masih banyak pegawai yang tidak dapat menyelesaikan pekerjaan sesuai dengan waktu yang telah ditentukan.

Kinerja pegawai juga dapat dipengaruhi oleh faktor disiplin kerja. Disiplin kerja merupakan hal yang penting dalam mencapai tujuan organisasi. Rasa tanggung jawab seseorang terhadap tugas-tugas yang diberikan dapat dicerminkan melalui disiplin kerjanya. Kedisiplinan dalam bekerja adalah suatu sikap menghormati, menghargai, tegas, patuh dan taat terhadap peraturan-peraturan yang berlaku, baik yang tertulis maupun tidak tertulis.

Disiplin erat hubungannya dengan sikap mental dan moral yang melekat pada diri seseorang, kesadaran mengandung unsur pengendalian diri dan dengan adanya pengendalian diri maka individu akan tertanam sikap mental moral yang tinggi. Salah satu aspek kekuatan sumber daya manusia dapat tercermin pada perilaku disiplin. Hal ini karena disiplin dapat mempunyai dampak kuat terhadap suatu organisasi untuk mencapai keberhasilan dalam mencapai tujuan

Dari hasil observasi pada Biro Administrasi Rumah Tangga Pimpinan Sekretariat Daerah Provinsi Banten, diketahui bahwa disiplin kerja yang ada masih lemah. Hal ini dikarenakan masih adanya pegawai yang masuk kerja terlambat atau pulang lebih cepat dari jam kerja, selama jam kerja pegawai melakukan kegiatan yang tidak ada kaitannya dengan tugas dan fungsi sehingga mempengaruhi ketepatan pelaksanaan tugas. Selain itu lemahnya disiplin kerja juga disebabkan oleh belum maksimalnya tanggung jawab yang dimiliki pegawai dalam hal membuat laporan kegiatan yang sudah dilaksanakan.

\section{B. Metode Penelitian}

Untuk metode pendekatan penelitian yang digunakan dalam penelitian ini yaitu metode korelasi untuk melihat seberapa besar pengaruh variabel bebas dan variabel terikat. Pendekatan ini lebih mengandalkan angkaangka berupa skor sebagai kerangka dasar analisis. Skor tersebut diperoleh dengan metode survei. Penelitian survei merupakan penelitian yang mengambil sampel dan satu populasi dengan menggunakan angket sebagai alat pengumpulan data yang pokok. Survei dimaksudkan untuk mempelajari sikap, keyakinan, nilai-nilai, demografi, tingkah laku, opini, kebiasaan, keinginan, ide-ide, dan tipe informasi lain yang diperlukan untuk kepentingan penelitian. (Mcmillan \& Schumacher, 2006:233).

Adapun dengan melihat pada data, fakta atau informasi yang diperoleh melalui survei tersebut dapat digambarkan kondisi masing-masing variabel yang diteliti sehingga memungkinkan untuk diketahui Pengaruh Budaya Kerja dan Disiplin Kerja baik sendirisendiri maupun secara bersama-sama terhadap Kinerja Aparatur Sipil Negara pada Biro Administrasi Rumah Tangga Pimpinan Sekretariat Daerah Provinsi Banten.

Adapun mengingat hakikat dari penelitian ini yaitu adalah kajian terhadap Kinerja Aparatur Sipil Negara pada Biro Administrasi Rumah Tangga Pimpinan Sekretariat Daerah Provinsi Banten, maka hasilnya diharapkan dapat menjadi pedoman atau bahan perbandingan dalam meningkatkan Kinerja Aparatur Sipil Negara. Hasil penelitian ini diharapkan dapat digunakan oleh pegawai di lingkungan Biro Administrasi Rumah Tangga Pimpinan Sekretariat Daerah Provinsi Banten.

Data pada penelitian ini akan disajikan secara redaksional serta akan menjelaskan pengaruh indikator-indikator Budaya Kerja dan Disiplin Kerja terhadap indikator yang terkandung dalam konsep Kinerja Aparatur 
Sipil Negara. Oleh karena itu, berdasarkan dimensi tujuan penjelasan, penelitian ini menerapkan dimensi penjelasan.

Untuk dimensi yang sesuai dengan penelitian ini adalah dimensi cross-sectional 'satu periode tertentu dalam satu waktu' yakni penelitian ini meliputi beberapa bulan dalam satu tahun yaitu antara bulan Maret 2017 sampai dengan Juli 2017.

Dalam penulisan penelitian ini, teknik pengumpulan data yang relevan dipilih penulis adalah dimensi survei karena terdapat populasi dari objek penelitian. Dari populasi tersebut kemudian ditarik sampel sesuatu dengan rumus-rumus statistik yang sesuai dengan teknik pengambilan sampel yang digunakan.

\section{Hasil Penelitan dan Pembahasan Hasil Penelitian}

Berikut hasil perhitungan pengaruh langsung dan pengaruh tidak langsung dari ketiga variabel penelitian.

\section{Tabel 1.}

Perhitungan Koefisien Jalur Pengaruh Budaya Kerja dan Disiplin Kerja terhadap Kinerja Aparatur Sipil Negara di Biro Administrasi Rumah Tangga Pimpinan Sekretariat Daerah

\begin{tabular}{|c|c|c|c|c|c|c|}
\hline \multicolumn{7}{|c|}{ Provinsi Banten } \\
\hline \multirow[b]{2}{*}{$\begin{array}{c}\text { Variab } \\
\text { el }\end{array}$} & \multirow{2}{*}{$\begin{array}{l}\text { Koef } \\
\text { Jalur } \\
\text { (pyx..) }\end{array}$} & \multicolumn{3}{|c|}{ Pengaruh } & \multirow[b]{2}{*}{$\begin{array}{l}\text { Si } \\
\text { g. }\end{array}$} & \multirow[b]{2}{*}{$\begin{array}{c}\text { Keterang } \\
\text { an }\end{array}$} \\
\hline & & $\begin{array}{c}\text { Lan } \\
\text { gsu } \\
\text { ng }\end{array}$ & $\begin{array}{c}\text { Tidak } \\
\text { Langsu } \\
\text { ng }\end{array}$ & $\begin{array}{c}\text { T } \\
\text { ot } \\
\text { al }\end{array}$ & & \\
\hline $\begin{array}{l}\text { Budaya } \\
\text { Kerja } \\
\text { (X1) }\end{array}$ & 0,473 & $\begin{array}{r}0,22 \\
4\end{array}$ & 0,258 & $\begin{array}{r}0, \\
48 \\
2 \\
\end{array}$ & $\begin{array}{r}0, \\
00 \\
0\end{array}$ & $\begin{array}{l}\text { Signifika } \\
\mathrm{n} \text { pd } \\
\square=0,05\end{array}$ \\
\hline $\begin{array}{l}\text { Disipli } \\
\text { n Kerja } \\
(\mathrm{X} 2)\end{array}$ & 0,181 & $\begin{array}{r}0,03 \\
3 \\
\end{array}$ & 0,258 & $\begin{array}{r}0, \\
29 \\
1 \\
\end{array}$ & $\begin{array}{r}0, \\
00 \\
0\end{array}$ & $\begin{array}{l}\text { Signifika } \\
\mathrm{n} \mathrm{pd} \\
\square=0,05\end{array}$ \\
\hline & Total & $\begin{array}{r}0,25 \\
6\end{array}$ & 0,516 & $\begin{array}{r}0, \\
77 \\
3\end{array}$ & & \\
\hline $\begin{array}{c}\text { Variab } \\
\text { el }\end{array}$ & Ryx1x2 & $\begin{array}{c}\text { Pen } \\
\text { gar } \\
\text { uh }\end{array}$ & & & $\begin{array}{l}\mathrm{Si} \\
\text { g. }\end{array}$ & \\
\hline $\begin{array}{l}\text { X1 dan } \\
\text { X2 } \\
\text { secara } \\
\text { bersam } \\
\text { a-sama }\end{array}$ & 0,879 & $\begin{array}{r}0,77 \\
3 \\
\end{array}$ & & & $\begin{array}{r}0, \\
00 \\
0\end{array}$ & \\
\hline & pye & $\begin{array}{l}\text { Pen } \\
\text { gar } \\
\text { uh }\end{array}$ & & & & \\
\hline $\begin{array}{l}\text { Variabe } \\
1 \text { luar } \\
(\square)\end{array}$ & 0,477 & $\begin{array}{r}0,22 \\
7 \\
\end{array}$ & & & & \\
\hline & Total & $\begin{array}{r}1,00 \\
00 \\
\end{array}$ & & & & \\
\hline
\end{tabular}

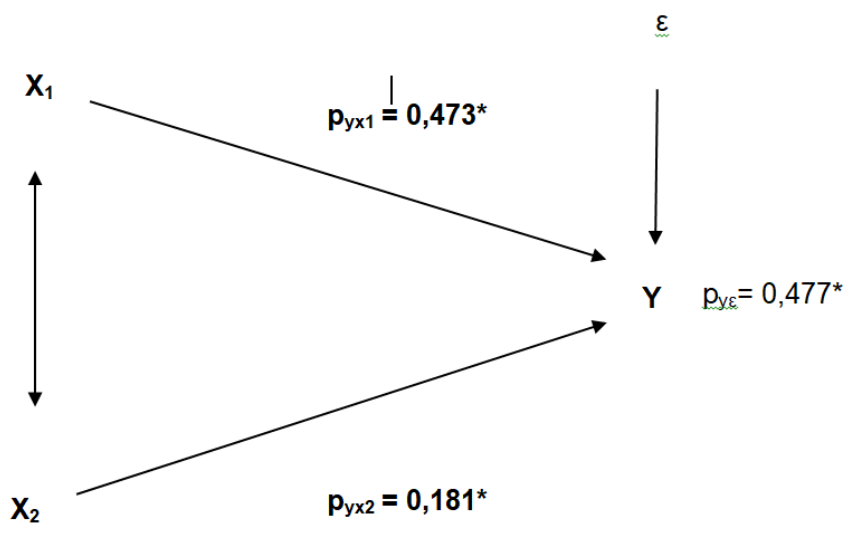

Gambar 4.5

Diagram Jalur yang Menunjukkan

Hubungan Kausal dari $X_{1}, X_{2}$ ke $Y$

\section{Keterangan :}

$r_{x 1 \times 2}$ : Koefisien korelasi antara variabel $X_{1}$ dengan variabel $X_{2}$

$\mathrm{p}_{\mathrm{yx} 1}$ : Koefisien jalur dari variabel eksogenus $\mathrm{X}_{1}$ ke variabel endogenus $\mathrm{Y}$

$\mathrm{p}_{\mathrm{yx} 2}$ : Koefisien jalur dari variabel eksogenus $\mathrm{X}_{2}$ ke variabel endogenus $\mathrm{Y}$

$\mathrm{p}_{\mathrm{y \varepsilon}}:$ Koefisien jalur residu

(*) : Menunjukkan bahwa koefisien jalur dan koefisien residu berarti pada taraf signifikansi $\alpha=0,05$ atau $5 \%$

Menurut diagram jalur tersebut, dapat dibuat persamaan struktural analisis jalur sebagai berikut :

$\hat{\mathbf{Y}}=\mathbf{p}_{\mathrm{yx} 1} \mathrm{X}_{1}+\mathbf{p}_{\mathrm{yx} 2} \mathrm{X}_{2}+\mathbf{p}_{\mathrm{y \varepsilon}} \varepsilon$ atau $\hat{\mathbf{Y}}=$ $0,473 X_{1}+0,181 X_{2}+0,477 \varepsilon$

Koefisien Jalur

Berdasarkan tabel Coefficients di atas, pada kolom Standardized Coefficients (Beta) diperoleh nilai koefisien jalur sebagai berikut :

$\mathrm{P}_{\mathrm{yx}}$ $=0,473$ dengan nilai

Sig. $=0,000$

$\mathrm{P}_{\mathrm{yx} 2}=0,181$ dengan nilai

Sig. $=0,000$

\section{Pengujian Hipotesis}

\section{Hipotesis Penelitian 1 :}

$\mathrm{H}_{0}: \mathrm{P}_{\mathrm{yx} 1}=0$ : (Budaya Kerja berpengaruh tidak signifikan terhadap Kinerja Aparatur Sipil Negara di Biro Administrasi Rumah Tangga Pimpinan Sekretariat Daerah Provinsi Banten). 
$\mathrm{H}_{\mathrm{A}}: \mathrm{P}_{\mathrm{yx} 1} \neq 0$ : (Budaya Kerja berpengaruh signifikan terhadap Kinerja Aparatur Sipil Negara di Biro Administrasi Rumah Tangga Pimpinan Sekretariat Daerah Provinsi Banten).

Dengan melihat tabel Coefficients di atas, diperoleh nilai sig. untuk koefisien jalur Budaya Kerja $=0,000$.

Karena nilai Sig. untuk $\mathrm{P}_{\mathrm{yx} 1}=0,000<\alpha=$ 0,05 , maka $\mathrm{H}_{\mathrm{o}}$ ditolak dan $\mathrm{H}_{\mathrm{A}}$ diterima.

Kesimpulan:

Budaya Kerja berpengaruh signifikan terhadap Kinerja Aparatur Sipil Negara di Biro Administrasi Rumah Tangga Pimpinan Sekretariat Daerah Provinsi Banten.

\section{Hipotesis Penelitian 2 :}

$\mathrm{H}_{0}: \mathrm{P}_{\mathrm{yx} 2}=0$ (Disiplin Kerja berpengaruh tidak signifikan terhadap Kinerja Aparatur Sipil Negara di Biro Administrasi Rumah Tangga Pimpinan Sekretariat Daerah Provinsi Banten).

$\mathrm{H}_{\mathrm{A}}: \mathrm{P}_{\mathrm{yx} 2} \neq 0$ (Disiplin Kerja berpengaruh signifikan terhadap Kinerja Aparatur Sipil Negara di Biro Administrasi Rumah Tangga Pimpinan Sekretariat Daerah Provinsi Banten).

Dengan melihat tabel Coefficients di atas, pada kolom Sig. diperoleh nilai sig. untuk koefisien jalur Disiplin Kerja $=0,000$. Karena nilai Sig. untuk $\mathrm{P}_{\mathrm{yx} 2}=0,000<\alpha=$ 0,05, maka $\mathrm{H}_{\mathrm{o}}$ ditolak dan $\mathrm{H}_{\mathrm{A}}$ diterima.

\section{Kesimpulan:}

Disiplin Kerja berpengaruh signifikan terhadap Kinerja Aparatur Sipil Negara di Biro Administrasi Rumah Tangga Pimpinan Sekretariat Daerah Provinsi Banten.

\section{Hipotesis Penelitian 3 :}

$\mathrm{H}_{0}: \rho_{\mathrm{yx} 1 \times 2}=0$ (Budaya Kerja dan Disiplin Kerja secara bersama-sama tidak berpengaruh signifikan terhadap Kinerja Aparatur Sipil Negara di Biro Administrasi Rumah Tangga Pimpinan Sekretariat Daerah Provinsi Banten).

$\mathrm{H}_{\mathrm{A}}: \rho_{\mathrm{yx} 1 \times 2} \neq 0$ (Budaya Kerja dan Disiplin Kerja secara bersama-sama berpengaruh signifikan terhadap Kinerja Aparatur Sipil Negara di Biro Administrasi Rumah Tangga Pimpinan Sekretariat Daerah Provinsi Banten).

Dengan melihat tabel Anova di atas diketahui bahwa nilai Sig. untuk hubungan antara Budaya Kerja dan Disiplin Kerja dengan Kinerja Aparatur Sipil Negara di Biro
Administrasi Rumah Tangga Pimpinan Sekretariat Daerah Provinsi Banten sama dengan 0,000. Karena nilai Sig. $=0,000<\alpha=$ 0,05, maka hubungan antara Budaya Kerja dan Disiplin Kerja dengan Kinerja Aparatur Sipil Negara di Biro Administrasi Rumah Tangga Pimpinan Sekretariat Daerah Provinsi Banten berbentuk linear.

\section{Kesimpulan:}

Budaya Kerja dan Disiplin Kerja secara bersama-sama berpengaruh signifikan terhadap Kinerja Aparatur Sipil Negara di Biro Administrasi Rumah Tangga Pimpinan Sekretariat Daerah Provinsi Banten.

Dari tabel Model Summary diketahui bahwa $\mathrm{R}_{\mathrm{yx} 1 \times 2}=0,879$.

4. Koefisien Jalur Residu

$$
\mathrm{P}_{\mathrm{y} \varepsilon}=\sqrt{1-R^{2}{ }_{y \times 1 \times 2}}=\sqrt{ } 1-0,773=\overline{0,477}
$$

5. Besarnya Pengaruh $X_{1}$ terhadap $Y$

- Pengaruh langsung : $\left(\mathrm{P}_{\mathrm{yx} 1}\right)\left(\mathrm{P}_{\mathrm{yx} 1}\right)$ $=\left(\mathrm{P}_{\mathrm{yx} 1}\right)^{2} \times 100 \%$

$$
\begin{aligned}
& =(0,473)^{2} \times 100 \% \\
& =0,224 \times 100 \% \\
& =\mathbf{2 2 , 4} \%
\end{aligned}
$$

- Pengaruh tidak langsung :

$=\left[\left(\mathrm{R}_{\mathrm{yx} 1 \times 2}\right)^{2}-\left(\left(\mathrm{p}_{\mathrm{yx} 1}\right)^{2}+\left(\mathrm{p}_{\mathrm{yx} 2}\right)^{2}\right)\right] / 2 \times 100 \%$

$=\left[(0,853)^{2}-\left((0,473)^{2}+(0,181)^{2}\right] / 2 \times 100 \%\right.$

$=0,2580 \times 100 \%$

$=\mathbf{2 5 , 8} \%$

- Pengaruh total : pengaruh langsung

+ pengaruh tidak langsung

$$
\begin{aligned}
& =22,4 \%+25,8 \% \\
& =\mathbf{4 8 , 2} \% .
\end{aligned}
$$

6. Besarnya Pengaruh $X_{2}$ terhadap $Y$

- Pengaruh langsung : $\left(\mathrm{P}_{\mathrm{yx} 2}\right)\left(\mathrm{P}_{\mathrm{yx} 2}\right)$ $=\left(\mathrm{P}_{\mathrm{y} \times 2}\right)^{2} \times 100 \%$

$$
\begin{aligned}
& =(0,181)^{2} \times 100 \% \\
& =0,033 \times 100 \% \\
& =\mathbf{3 , 3} \%
\end{aligned}
$$

- Pengaruh tidak langsung

$=\left[\left(\mathrm{R}_{\mathrm{yx} 1 \times 2}\right)^{2}-\left(\left(\mathrm{p}_{\mathrm{yx} 1}\right)^{2}+\left(\mathrm{p}_{\mathrm{yx} 2}\right)^{2}\right)\right] / 2 \times 100 \%$

$=\left[(0,853)^{2}-\left((0,473)^{2}+(0,181)^{2}\right] / 2 \times 100 \%\right.$

$=0,2580 \times 100 \%$

$=\mathbf{2 5 , 8} \%$

- Pengaruh total = pengaruh langsung

+ pengaruh tidak langsung

$$
=3,3 \%+25,8 \%
$$




$$
=\mathbf{2 9 , 1} \% \text {. }
$$

7. Pengaruh gabungan dari $X_{1}$ dan $X_{2}$ secara bersama-sama terhadap $Y$ sama dengan:

$=$ Pengaruh total Budaya Kerja + pengaruh total Disiplin Kerja

$=48,2 \%+29,1 \%=77,3 \%$

(sesuai dengan $R$ Square SPSS)

8. Pengaruh variabel lain selain $X_{1}$ dan $X_{2}$ terhadap $\mathbf{Y}$

$\left(\mathrm{P}_{\mathrm{y} \varepsilon}\right)_{\%}^{2}=\left(1-\mathrm{R}_{\mathrm{yx} 1 \mathrm{x} 2}^{2}\right)=1-0,773=0,227=22,7$

\section{Pembahasan Hasil Penelitian}

A. Pengaruh Budaya Kerja terhadap Kinerja Aparatur Sipil Negara Di Biro Administrasi Rumah Tangga Pimpinan Sekretariat Daerah Provinsi Banten

Untuk mengetahui besarnya nilai pengaruh total dari Budaya Kerja terhadap Kinerja Aparatur Sipil Negara di Biro Administrasi Rumah Tangga Pimpinan Sekretariat Daerah Provinsi Banten terdiri dari pengaruh langsung ditambah dengan pengaruh tidak langsung. Dari hasil pengolahan data diketahui besarnya pengaruh langsung dari Budaya Kerja terhadap Kinerja Aparatur Sipil Negara di Biro Administrasi Rumah Tangga Pimpinan Sekretariat Daerah Provinsi Banten adalah $22,4 \%$, sedangkan besarnya pengaruh tidak langsungnya adalah 25,8 \%. Jadi besarnya pengaruh total dari Budaya Kerja terhadap Kinerja Aparatur Sipil Negara di Biro Administrasi Rumah Tangga Pimpinan Sekretariat Daerah Provinsi Banten adalah $22,4 \%+25,8 \%=48,2 \%$.

Dari uraian di atas dapat disimpulkan bahwa Budaya Kerja berpengaruh positif dan signifikan terhadap Kinerja Aparatur Sipil Negara di Biro Administrasi Rumah Tangga Pimpinan Sekretariat Daerah Provinsi Banten. Hal ini sesuai dengan teori bahwa budaya kerja adalah anggapan dasar tentang kerja, dimana berbentuk pendirian atau basic assumption tentang nilai-nilai dan normanorma yang dilaksanakan dalam pekerjaan pada suatu organisasi, dengan dimensi: 1 sikap terhadap pekerjaan, 2. perilaku ketika bekerja, 3. kenampakan, dan 4. etos kerja Paramita (2005:208).

B. Pengaruh Disiplin Kerja terhadap Kinerja Aparatur Sipil Negara Di Biro Administrasi Rumah Tangga Pimpinan Sekretariat Daerah Provinsi Banten
Untuk mengetahui besarnya nilai pengaruh total dari Disiplin Kerja terhadap Kinerja Aparatur Sipil Negara di Biro Administrasi Rumah Tangga Pimpinan Sekretariat Daerah Provinsi Banten terdiri dari pengaruh langsung ditambah dengan pengaruh tidak langsung. Dari hasil pengolahan data diketahui besarnya pengaruh langsung dari Disiplin Kerja terhadap Kinerja Aparatur Sipil Negara di Biro Administrasi Rumah Tangga Pimpinan Sekretariat Daerah Provinsi Banten adalah 3,3\%, sedangkan besarnya pengaruh tidak langsungnya adalah 25,8 \%. Jadi besarnya pengaruh total dari Disiplin Kerja terhadap Kinerja Aparatur Sipil Negara di Biro Administrasi Rumah Tangga Pimpinan Sekretariat Daerah Provinsi Banten adalah 3,3 $\%+25,8 \%=29,1 \%$.

Dari uraian di atas dapat disimpulkan bahwa Disiplin Kerja berpengaruh positif dan signifikan terhadap Kinerja Aparatur Sipil Negara di Biro Administrasi Rumah Tangga Pimpinan Sekretariat Daerah Provinsi Banten. Hal ini sesuai dengan teori bahwa disiplin kerja adalah suatu kondisi yang tercipta dan terbentuk melalui proses dan serangkaian perilaku yang menunjukkan nilai ketaatan, kejujuran, tangggung jawab, dan ketegasan. (Soegeng, 2004:37). Dengan demikian dimensi dari disiplin terdiri dari : 1) Ketaatan; 2) Kejujuran; 3) Tanggung jawab; dan 4) Ketegasan.

C. Pengaruh Budaya Kerja dan Disiplin Kerja Secara Bersama-sama terhadap Kinerja Aparatur Sipil Negara Di Biro Administrasi Rumah Tangga Pimpinan Sekretariat Daerah Provinsi Banten

Adapun untuk besarnya nilai pengaruh dari Budaya Kerja dan Disiplin Kerja secara bersama-sama terhadap Kinerja Aparatur Sipil Negara di Biro Administrasi Rumah Tangga Pimpinan Sekretariat Daerah Provinsi Banten adalah sebesar 77,3\% yang diperoleh dari nilai $\left(\mathrm{R}_{\mathrm{yx} 1 \times 2}\right)^{2} \times 100 \%$. Besarnya pengaruh Budaya Kerja dan Disiplin Kerja secara bersama-sama terhadap Kinerja Aparatur Sipil Negara di Biro Administrasi Rumah Tangga Pimpinan Sekretariat Daerah Provinsi Banten juga dapat dihitung dengan menjumlahkan pengaruh total dari Budaya Kerja dengan pengaruh total dari Disiplin Kerja yaitu: 48,2 $\%+29,1 \%=77,3 \%$. 
Dari uraian di atas dapat disimpulkan bahwa Budaya Kerja dan Disiplin Kerja secara bersama-sama berpengaruh positif dan signifikan terhadap Kinerja Aparatur Sipil Negara di Biro Administrasi Rumah Tangga Pimpinan Sekretariat Daerah Provinsi Banten, yaitu sebesar 77,3\%. Sedangkan sisa $22,7 \%$ dipengaruhi oleh faktor dari variabel lain. Hal ini sesuai dengan teori menurut As'ad dalam bukunya Pshikologi Industri (1995:47-48) Job performance ialah Succesful role achievement yang diperoleh seseorang dari perbuatannya. Dari batasan-batasan tersebut jelaslah bahwa yang dimaksud dengan Job Performance adalah hasil yang dicapai oleh seseorang menurut ukuran yang berlaku untuk pekerjaan yang bersangkutan. Tingkat keberhasilan seseorang di dalam melaksanakan tugas pekerjannya dinamakan level of performance. Orang yang level of permormance-nya tinggi dikatakan orang yang produktif, sedang orang yang level of performance-nya tindak mencapai standar disebut tidak produktif atau performance-nya rendah. Adapun dimensi dari Kinerja Pegawai adalah hasil kerja, efisiensi, dan efektivitas.

\section{1.}

\section{Kesimpulan dan Rekomendasi Kesimpulan}

Dengan melihat hasil penelitian dan pembahasan yang telah dilakukan pada bab sebelumnya mengenai pengaruh Budaya Kerja dan Disiplin Kerja baik sendiri-sendiri maupun bersama-sama terhadap Kinerja Aparatur Sipil Negara di Biro Administrasi Rumah Tangga Pimpinan Sekretariat Daerah Provinsi Banten, maka simpulan dari penelitian ini adalah sebagai berikut :

1. Budaya Kerja berpengaruh signifikan terhadap Kinerja Aparatur Sipil Negara di Biro Administrasi Rumah Tangga Pimpinan Sekretariat Daerah Provinsi Banten. Pengaruhnya sebesar 48,2 \% dengan perincian: pengaruh langsungnya sebesar 22,4 $\%$ dan pengaruh tidak langsungnya (melalui Disiplin Kerja) sebesar 25,8 \% .

2. Disiplin Kerja berpengaruh signifikan terhadap Kinerja Aparatur Sipil Negara di Biro Administrasi Rumah Tangga Pimpinan Sekretariat Daerah Provinsi Banten. Pengaruhnya sebesar 29,1 \% dengan perincian: pengaruh langsungnya sebesar 3,3 $\%$ dan pengaruh tidak langsungnya (melalui Budaya Kerja) sebesar 25,8\%.
3. Budaya Kerja dan Disiplin Kerja secara bersama-sama berpengaruh signifikan terhadap Kinerja Aparatur Sipil Negara di Biro Administrasi Rumah Tangga Pimpinan Sekretariat Daerah Provinsi Banten. Pengaruhnya sebesar 77,3 \% dengan perincian: pengaruh Budaya Kerja sebesar 48,2 \% dan pengaruh Disiplin Kerja sebesar $29,1 \%$, sedangkan sisanya sebesar $22,7 \%$ dipengaruhi oleh variabel lain.

\section{REKOMENDASI}

Berdasarkan hasil penelitian di atas, maka ada beberapa saran yang dapat penulis berikan, yaitu :

1. Pimpinan Biro Administrasi Rumah Tangga Pimpinan harus melakukan pembenahan budaya kerja yang dapat dilakukan melalui sosialisasi nilai-nilai kerja yang ada sehingga pegawai lebih menghayati dan memahami akan nilai-nilai tersebut. Kejelasan nilai budaya kerja perlu dibenahi agar pegawai dapat lebih memahami akan nilai-nilai tersebut.

2. Disarankan agar meningkatkan disiplin kerja yang dilakukan mulai dari semua level jabatan melalui penilaian pelaksanaan disiplin kerja. Disamping itu adanya reward bagi pegawai yang menjalankan disiplin kerja dengan baik, serta adanya hukuman yang tegas bagi pegawai yang melanggar Disiplin Kerja.

3. Disarankan agar peneliti berikutnya melakukan penelitian lebih lanjut agar diketahui faktor lain yang mempengaruhi Kinerja Aparatur Sipil Negara selain faktor Budaya Kerja dan Disiplin Kerja, baik secara internal maupun eksternal.

\section{Daftar Pustaka}

As'ad, M. 1995. Seri Ilmu SDM:Psikologi Industri. Edisi keempat. Liberty, Yogyakarta.

Davis, K. dan Newstrom. 2000. Perilaku Dalam Organisasi. Edisi ketujuh. Jakarta: Penerbit Erlangga.

Dessler, G. 2004. Manajemen Sumber Daya Manusia. Edisi Bahasa Indonesia. Jakarta, Prenhallindo.

Flippo E. B. 1996. Manajemen Personalia. Jilid I. Edisi Ketujuh. Alih Bahasa Moh. Masud. Jakarta: Airlangga. 2001. Manajemen Personalia dan Sumber Daya Manusia. Edisi keenam. Jakarta: Erlangga. 
Handoko, T. H. 2007. Manajemen Personalia dan Sumber Daya Manusia. Edisi 2. Yogyakarta: BPFE

2010, Manajemen. Yogyakarta: BPFE

Hariandja, M. T. E. 2006. Manajemen Sumber Daya Manusia, Pengadaan, Pengkompensasian, dan Peningkatan Produktivitas Karyawan. Jakarta: PT. Grasindo.

Hasibuan, M. SP. 2005. Manajemen Sumber Daya Manusia. Jakarta: Bumi Aksara.

Husein, U. 2006. Metode Riset Penilaian Organisasi. Jakarta: PT. Gramedia Pustaka Utama.

Ilyas, Y. 2005. Kinerja: Teori, Penilaian, dan Penelitian. Penerbit: Sinar Baru Bandung.

Mangkunegara, A. A., dan Anwar, P. 2001. Manajemen Sumber Daya Manusia dalam Perusahaan. Bandung: Remaja Rosdakarya.

McMillan, J. H., \& Schumacher, S. 2006. Research in education: A conceptual introduction (5th ed.). New York: Longman.

Moekijat. 1979. Manajemen Kepegawaian. Bandung: Alumni.

Moenir, AS. 1983. Manajemen Pelayanan Umum di Indonesia. Jakarta: Ghalia Indonesia.

Munandar. 2008. Psikologi Industri dan Organisasi. Jakarta: UI Press.

Sadili. 2009. Manajemen Sumber Daya Manusia. Yogyakarta: Pustaka Pelajar

Nawawi, H. 2001. Manajemen Sumber Daya Manusia Untuk Bisnis Yang Kompetitif. Yogyakarta: Gadjah Mada University Press.

Ndraha, T., \& Rivai, V. 2004. Kepemimpinan dan Perilaku Organisasi. Jakarta: PT. Rajagrafindo Persada.

Notowidagdo. 2002. Manajemen Sumber Daya Manusia. Yogyakarta: Gadjah Mada University Press.

Nurlita, W. 1988. Dasar-Dasar Produksi. Jakarta: Karunika.

Paramita. 2005. Sumber Daya Manusia dan Produktivitas Kerja. Jakarta: Ilham Jaya

Prawirosentono, S. 1999. Kebijakan Kinerja Karyawan. Yogyakarta: BPFE.

Riduwan. 2003. Skala Pengukuran Variabelvariabel Penelitian. Bandung: CV Alfabeta.
Robin, S. P. 2002. Organizational Behavior, New York: Prentice-Hall Co.

Siagian, P. S. 2004. Manajemen Sumber Daya Manusia. Jakarta: Bumi Aksara.

$$
2007 . \quad \text { Teori }
$$
Motivasi dan Aplikasinya. Cet.3. Jakarta: Rineka Cipta.

Simamora, H. 1995. Manajemen Sumber Daya Manusia. Yogyakarta: P. STIE YPKN.

Sinamo, JH. 2002. Delapan Etos Kerja Profesional : Navigator Anda Menuju Sukses. Cetakan Kelima. Jakarta: Penerbit Institut Darma Mahardika.

Sinungan, M. 2009. Produktivitas Apa dan Bagaimana. Jakarta: Bumi Aksara.

Siswanto, B. 2005. Manajemen Tenaga Kerja Indonesia Pendekatan Administratif dan Operasional. Jakarta: Bumi Aksara.

Soegeng, F. A. 2004. Perilaku Organisasi. Jakarta: Bumi Aksara.

Soeprihanto, J. 2007. Penilaian Kinerja dan Pengembangan Karyawan. Yogyakarta: BPFE.

Stoner, A. F. J., dan Freeman , R. E. 1997. Management. New York: Prentice-Hall International Inc.

Sugiyono. 2004. Metode Penelitian Bisnis. Jakarta: Rineka.

2007. "Metode Penelitian Kuantitatif Kualitatif dan $R \& D "$. Bandung: Alfabeta.

Sukarna, dkk. 1976. Dasar-dasar Pendidikan Science. Jakarta: PT. Bhratara.

Sumarsono, S. 2008. Ekonomi Manajemen Sumber Daya Manusia dan Ketenagakerjaan. Jogyakarta: Graha Ilmu.

Suradinata, E. 2004. Manajemen Pemerintahan dan Otonomi Daerah. Bandung: Ramadhan.

Swan, J. A. dan Stapp, W. B. 1999. Environmental Education: Strategies Toward a More Livable Future. N.Y.. London: John Wiley \& Sons.

Syaidam, G. 2003. Manajemen Sumber Daya Manusia, Suatu Pendekatan Mikro. Jakarta: Djambatan.

Tampubolon, M. P. 2004. Perilaku Keorganisasian (Organization Behavior). Cetakan Pertama. Jakarta: Ghalia Indonesia.

Tika, M. P. 2006. Budaya Organisasi dan Peningkatan Kinerja Organisasi. Jakarta: Rieanika. 
Triguno, S. 2004. Pengukuran Kinerja. Jakarta: Gramedia Asri Media.
Wirjo, S. 1993. Wawasan Kerja Aparatur Negara. Jakarta: Pustaka Jaya. 